\title{
Relative Importance of Abiotic and Biotic Factors to the Management of the Northern Shrimp (Pandalus Borealis) Fishery on the Scotian Shelf
}

\author{
P. A. Koeller \\ Department of Fisheries and Oceans, Bedford Institute of Oceanography \\ P. O. Box 1006, Dartmouth, Nova Scotia B2Y 4A2, Canada
}

\begin{abstract}
The biology of the northern shrimp, Pandalus borealis, on the Scotian Shelf is discussed in relation to the Gulf of Maine and Newfoundland Shelf stocks. The Scotian Shelf is an area of transition for $P$. borealis with a change in oceanographic characteristics in the mid shelf area that has resulted in populations with characteristics of both more southern and more northern stocks. The commercially important population on the eastern Scotian Shelf is restricted to small areas of suitable habitat despite favorable temperatures over a wide area. On the western Scotian Shelf a small population inhabits relatively small areas of marginally suitable temperatures, despite large areas of suitable habitat. Commercially important concentrations in this area appear only rarely after temperatures decrease to more favorable levels. Differences in migration patterns between the Scotian Shelf stock and stocks to the north and south are related to differences in temperature regimes. While shrimp populations on the Scotian Shelf are influenced by water temperatures and habitat availability, predation pressure is also a significant determinant of abundance. The implications for the management of shrimp fisheries in the area are discussed.
\end{abstract}

Keywords: migration, northern shrimp, Pandalus borealis, predation, Scotian Shelf, temperature

\section{Introduction}

Pandalus borealis is a circumpolar species of shrimp, which is most abundant north of $46^{\circ} \mathrm{N}$ in the western North Atlantic. South of this parallel, i.e. on the Scotian Shelf and in the Gulf of Maine, this species approaches its distributional and, by inference, its physiological and/or ecological limits. Its preferred temperature range is $1-6^{\circ} \mathrm{C}$ (Shumway et al., 1985). In the Gulf of Maine (the southern limit of its Atlantic distribution), landings (Dow, 1977) and recruitment (Richards et al., MS 1996) have been inversely related to sea water temperatures, with mechanisms proposed by Appolonio et al. (MS 1984) and Tande et al., (1993). The literature shows both direct and inverse temperature-abundance relationships for more northern stocks (Nilssen and Hopkins, 1991) but population fluctuations in these northern stocks have also been linked to predator abundance (e.g, Stefánsson et al., MS 1994, Stefánsson and Pálsson, 1998).

On the Scotian Shelf, $P$. borealis is the object of a relatively small (1999 catches 5000 tons ), recently established, offshore trawl fishery and a developing inshore trap fishery (Koeller et al., 1995; Koeller et al.,
MS 1999). The purpose of this paper is to contrast the available abiotic and biotic information on the Scotian shelf with information on shrimp stocks to the north and south, and to discuss the broad management implications of the results. The working hypothesis is that temperatures are more important than predators in regulating southern shrimp stocks, and vice versa in northern stocks. The Scotian Shelf should exhibit characteristics intermediate to the southern and northern populations which bracket it geographically.

\section{Methods}

Bathymetric information of the study area was obtained as digitized depth contours from the Canadian Hydrographic Service. The distribution of shrimp habitat can be inferred from surficial geology maps published by the Atlantic Geosciences Centre, Bedford Institute of Oceanography, Dartmouth, Nova Scotia. Historical bottom temperature data in areas of shrimp distribution were obtained from the Marine Environmental Data Service (MEDS), Ottawa. Bottom temperatures were also recorded continuously at a fixed location (depth $100 \mathrm{~m}$ ) off Canso, Nova Scotia, using Vemco temperature recorders. 
Information on shrimp distribution was obtained during Department of Fisheries and Oceans (DFO) stratified random groundfish surveys (Halliday and Koeller, 1981) conducted on the entire Scotian Shelf from 1970 to 1983, DFO shrimp surveys conducted on the eastern Scotian Shelf twice per year (spring and autumn) on RV E.E. Prince from 1982 to 1988 (Etter and Mohn, MS 1989), and cooperative DFO-industry shrimp surveys conducted on the eastern Scotian Shelf in 1995-97 (Koeller et al., MS 1999). Groundfish surveys which recorded shrimp catches covered the entire Scotian Shelf once per year (summer) from 1971-78 and 3 times per year (spring, summer, autumn) from 1979-83. The stratification scheme of these surveys ensured that the 2168 randomly chosen stations completed between 1970 and 1983 were relatively evenly distributed on the entire Scotian Shelf covering all areas, depths $(<400 \mathrm{~m})$ and habitat types. Information on shrimp distributions on the Scotian Shelf and Bay of Fundy were also available from exploratory surveys conducted by the Nova Scotia and New Brunswick Departments of Fisheries from 1965-70 (MacPhail and MacDonald, 1965; Johnson, 1966; Murray, 1967; Scullion, 1969; Cadegan, 1970; Pettigrew, 1970) and by DFO (Ang, MS 1993). Information on the inshore distribution and migrations of shrimp was obtained from trapping surveys conducted in 1994-97 using Maine-style shrimp traps (Koeller et al., 1995) and from the DFO-industry shrimp surveys in 1995-97 (Koeller et al., MS 1999).

Total predator abundance in the Gulf of Maine, determined from groundfish surveys, was obtained from available published information (NOAA, 1998). Predator abundances were calculated from groundfish survey data collected by DFO on the Scotian Shelf and on the Newfoundland-Labrador Shelf. Most groundfish feed on crustaceans at some point in their life history, and shrimp are often identified as an important component of their diet. In addition, the important commercial groundfish species which comprise most of the biomass in the three areas considered have all been identified as predators of shrimp (Atlantic cod, silver hake, Greenland halibut, Sebastes sp., and various flatfish species). Consequently, total groundfish abundance in each area, measured by the mean stratified catchper-tow of all groundfish species in strata (Doubleday, 1981) coinciding with known areas of shrimp distribution, was considered to be directly proportional to predation pressure in each area.

Shrimp abundance in the Gulf of Maine was obtained from survey data given in Armstrong et al.
(1997). On the Scotian Shelf and Newfoundland Labrador Shelf shrimp abundance indices from surveys were not consistently available, so commercial catchper-unit-effort data from the relevant stock assessment documents were used as a proxy (Koeller et al., MS 1999; Parsons and Veitch, MS 1998).

Multiple regression analysis was used to determine if water temperatures and predator abundance could explain a significant amount of the variation in shrimp abundance in the three areas according to the working hypothesis i.e. temperatures would explain more of the variation in shrimp abundance in the Gulf of Maine, predator abundance would be more important on the Newfoundland Shelf, and both factors would come into play on the Scotian Shelf. Correlations of shrimp and predators were conducted without lags because natural (predation) mortality should affect a shrimp population immediately. Since temperature appears to influence survival of shrimp eggs or larvae (Appolonio et al., MS 1984; Shumway et al., 1985; Richards et al., MS 1996) its affect on shrimp populations would not be detected until shrimp become available to the fishing/survey gear, consequently lags of 4 years were used for temperature data. Age specific abundance data were not available, so the lagged temperature data were compared with the total abundance estimate, which was composed of all age classes. This was appropriate because the time series involved were long relative to the short shrimp life span and the gears used were selective for older ages.

Sex and reproductive condition of individual shrimp was determined using the methods of Allen (1959) and McCrary (1971). Samples for detailed analysis including carapace length, individual weights and reproductive condition were collected from all survey sets and representative commercial catches. Where possible, each sample consisted of a minimum of 500 animals to ensure adequate representation of the catch and separation of life history stages.

In this paper the "eastern Scotian Shelf" includes Louisbourg, Canso, and Misaine Holes, The Gully, Chedebucto Bay, and the inshore area known as The Noodles; the "central Scotian Shelf" includes LaHave and Emerald basins; the "western Scotian Shelf" includes the Bay of Fundy and Roseway Basin; and the Gulf of Maine includes Jordan and Crowell Basins and areas to the west (Fig. 1). The term "shrimp" refers exclusively to $P$. borealis. 


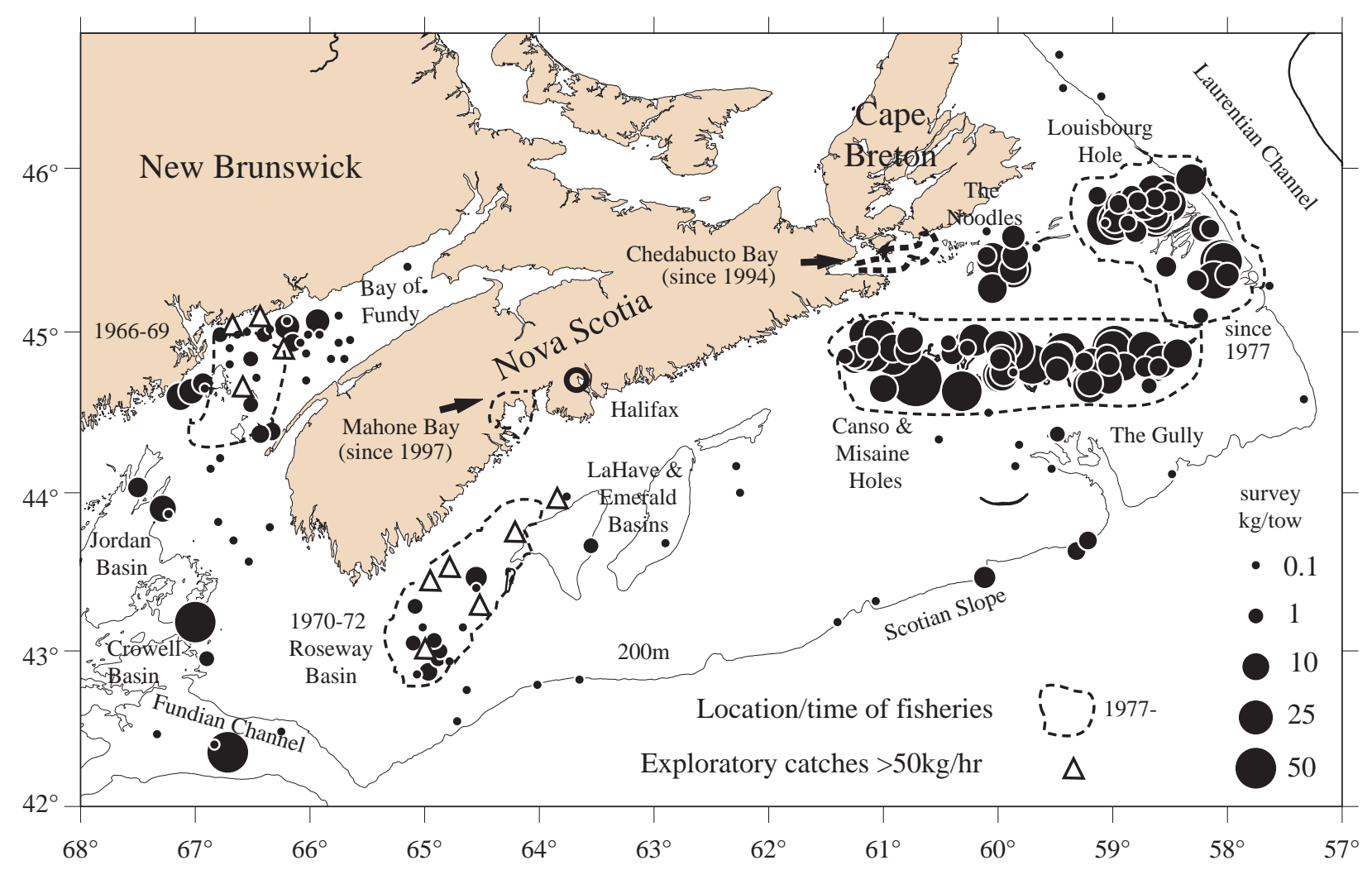

Fig. 1. Scotian Shelf and Bay of Fundy showing the distribution of catches from DFO groundfish surveys (1970-84), location of significant exploratory survey catches (1965-70, 1992-93), and the location of historical fisheries. The place names used in the text are also given.

\section{Results}

Groundfish surveys, which covered the entire Scotian Shelf, show that major concentrations of shrimp were restricted to the eastern Scotian Shelf throughout the study period (Fig. 1). Except for the shallower Noodles area shrimp on the eastern shelf were largely restricted to the "shrimp holes" (Louisbourg, Canso and Misaine) at depths $>200 \mathrm{~m}$ where the present fishery concentrates. The trawl fishery on the eastern Scotian Shelf began in the late-1970s. In the 1990s inshore trap fisheries appeared in Chedebucto and Mahone Bays (Fig. 1).

Two minor concentrations of survey catches were evident on the western shelf in areas where fisheries occurred in the late-1960s. These fisheries began in the Bay of Fundy in the mid-1960s and moved to the Roseway Basin area in the late-1960s when Bay of Fundy catch rates declined sharply. This fishery had largely disappeared by 1970 and Roseway Basin catches declined shortly after that (Pettigrew, 1970; Scullion, 1969; Cadegan, 1970). Shrimp have not been found in commercial quantities on the western shelf since then, despite extensive exploratory surveys in 1992-93 (Ang, MS 1993) and the presence of a fleet of vessels licensed to fish shrimp only in this area. Commercial concentrations or significant survey catches have never been found in the central Scotian Shelf area.

Shrimp habitat i.e. LaHave clay, is found mainly in the deep basins of the Scotian Shelf. The $200 \mathrm{~m}$ depth contour roughly outlines most patches of this substrate, with the notable exception of shallower water in the Bay of Fundy, The Noodles, around Roseway Basin, and in the area immediately east of Emerald Basin (Fig. 2).

Temperatures for July 1996 (Fig. 2) showed persistent features evident every year in plots of bottom temperatures from nearly 30 years of summer groundfish surveys, including relatively cold temperatures $\left(1-3^{\circ} \mathrm{C}\right)$ on the eastern shelf, warm temperatures $\left(>10^{\circ} \mathrm{C}\right)$ on the central shelf and moderate temperatures $\left(3-10^{\circ} \mathrm{C}\right)$ to the west. Note that the coldest temperatures on the 


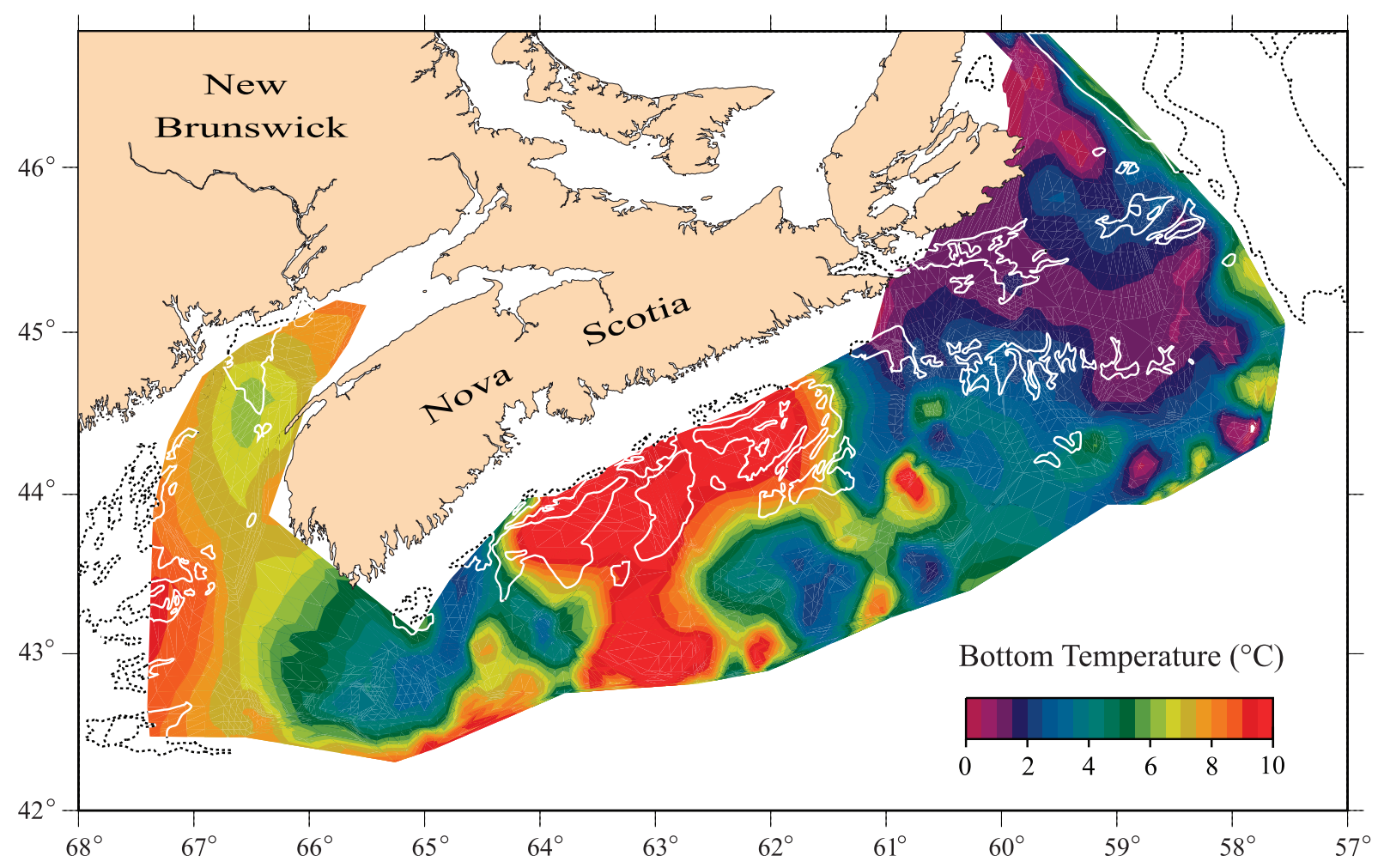

Fig. 2. Scotian Shelf and Bay of Fundy showing the distribution of bottom temperatures during the July 1996 groundfish survey and the distribution of shrimp habitat (LaHave clay, white line).

eastern shelf covered an area that is much wider than the area of shrimp distribution, while the coldest temperatures on the western Scotian Shelf were restricted to smaller patches in the Bay of Fundy and in the Roseway Basin area. Note also that the areas with the largest amount of shrimp habitat (central Scotian Shelf, and eastern Gulf of Maine) had temperatures above the preferred range, and no sustained shrimp concentrations. On the western Scotian Shelf, shrimp concentrated in two relatively small patches of habitat i.e. Bay of Fundy and Roseway Basin (Fig. 1), where temperatures were cooler, despite a large amount of available habitat elsewhere. The percentages of the total areas of bottom within and above the preferred temperature range on the central-western and eastern Scotian Shelf in July since 1970, and the proportion of each area that is shrimp habitat confirm the persistence of the very different temperature-habitat regimes in these areas (Fig. 3).

Summer surveys on the Scotian Shelf between 1995 and 1997 showed significant concentrations of females both inshore (i.e. the Noodles, Fig. 1) and offshore (Table 1). High densities of juveniles were found both inshore and offshore, indicating that breed- ing occurs in both areas. In addition, there were no statistically significant differences in abundance between spring and autumn surveys conducted between 1982-88 that would suggest large scale seasonal emigration from the offshore. Effort in the trawl fishery has traditionally concentrated in the offshore holes throughout the year until recently when the inshore concentration was discovered (Koeller et al., MS 1999). Both inshore and offshore areas are fished simultaneously throughout the year and the fishery does not follow large shrimp inshore during their winter migration as in the Gulf of Maine. There was a significant correlation between mean carapace length and depth in the offshore holes during both spring and autumn (Fig. 4).

Information from the inshore Mahone Bay winter trap fishery (Fig. 1) indicates that trappers catch mostly females $(>80 \%$ by number), most of which are ovigerous ( $>90 \%$ by number) (Table 2 ). Despite the selectivity of fixed gear for larger animals, the identical traps in Chedebucto Bay caught more juveniles and males, and the percentage of ovigerous females was much lower than in Mahone Bay. The Chedebucto Bay fishery is conducted from late summer-autumn 


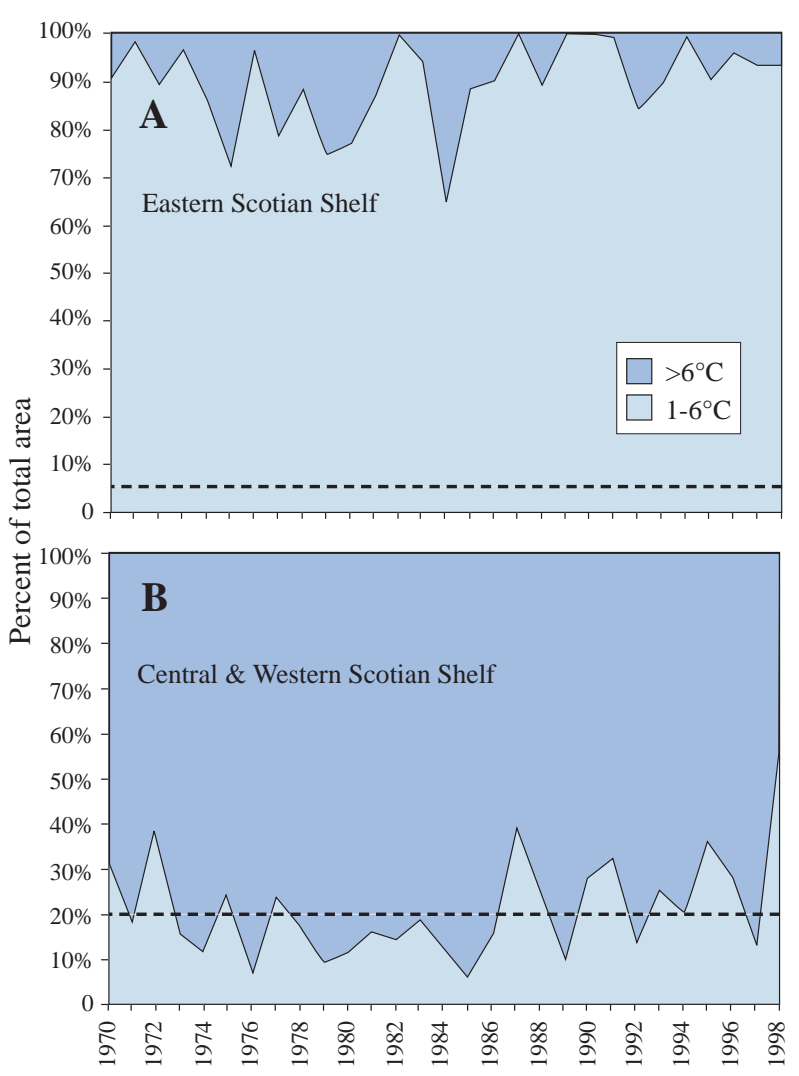

Fig. 3. Percent of the area of bottom on the A) eastern and B) central-western Scotian Shelf having July bottom temperatures within $\left(1-6^{\circ} \mathrm{C}\right)$ and above $\left(>6^{\circ} \mathrm{C}\right)$ the preferred temperature range of $P$. borealis. The horizontal lines indicate the percentage of each area which is LaHave Clay (shrimp habitat).

to spring, and typically catches decrease to negligible levels in spring-early summer when temperatures in the Bay drop below $1^{\circ} \mathrm{C}$ (Fig. 5). Trawl surveys at this time (June) showed very low numbers of females in Chedebucto Bay itself, but high concentrations immediately outside the Bay (Koeller, MS 1996; Koeller et al., MS 1999). During the Chedebucto Bay trap fishery, catch rates typically fluctuate several times during the season in phase with changes in the percentage of ovigerous females as shown by the 1996-97 fishery in Fig. 6.

Differences in the seasonal changes in surface and deeper $(>100 \mathrm{~m})$ water temperatures in the western Gulf of Maine, Scotian Shelf and Newfoundland-Labrador Shelf along with the preferred temperature range of P. borealis are given in Fig. 7.

Long-term changes in the abundance of shrimp on the Scotian Shelf and in the Gulf of Maine are shown in Fig. 8. Since commercial catches in the Gulf of Maine closely track shrimp abundance estimates from groundfish surveys (Armstrong et al., 1997), total catch was used as a proxy for abundance in the Gulf of Maine and western Scotian Shelf, while catch-per-unit-effort from commercial shrimp trawlers was used as an abundance index for the eastern Scotian Shelf in Fig. 8A. The western Scotian Shelf fishery was short-lived but catches peaked in the same year as in the Gulf of Maine, although they were an order of magnitude smaller. Abundance on the eastern Scotian Shelf was high in the late-1970s when the Gulf of Maine fishery had collapsed, and it was at its lowest in the mid-1980s, when the Gulf of Maine fishery had recovered. Eastern Scotian Shelf abundance increased greatly in the 1990s when Gulf of Maine catches were falling. Relative changes in shrimp abundance from groundfish survey indices (Fig. 8B) reflect the similarity of catch data in the Gulf of Maine and the western Scotian Shelf, and the different pattern on the eastern Scotian Shelf, i.e. relative abundance was high in the Gulf of Maine and western Scotian Shelf during the early-1970s when it was low on the eastern Scotian Shelf. However, as with historical commercial catches, survey catches and densities on the western Scotian Shelf were about an order of magnitude lower than the Gulf of Maine or the eastern Scotian Shelf (Figure 8A,B)

Average bottom $(>100 \mathrm{~m})$ temperatures in the western Gulf of Maine, on the eastern Scotian Shelf and on the Newfoundland-Labrador Shelf since the late-1970s were near the top, middle and bottom of P. borealis temperature range, respectively (Fig. 9A). The long term bottom temperature anomaly in the Gulf of Maine generally decreased until the late-1960s, reaching historical lows a few years before the record high catches and abundance indices in the early-1970s (Fig 8A, Fig. 9B). Conversely, bottom temperatures in the Gulf of Maine increased from the late-1960s to the late-1970s and reached historical highs a few years before the record low catches and abundance indices of the early-1980s. Except for recent years, temperatures in the Gulf of Maine appear to have been decreasing since the late-1970s. Eastern Scotian Shelf temperatures showed a decreasing trend throughout the 1980 s and 1990 s when the shrimp population cycled through periods of low and high abundance. Bottom temperatures on the Newfoundland-Labrador Shelf also decreased during the 1980s and 1990s, but they increased in recent years. Shrimp abundance tends to mirror predator abundance in all three areas (Fig. 10). A multiple regression analysis showed that, while the model explained a relatively small amount of the variance in the data, predation was the only 
TABLE 1. Densities of females and juveniles in the inshore and offshore areas from DFO shrimp surveys on the eastern Scotian Shelf.

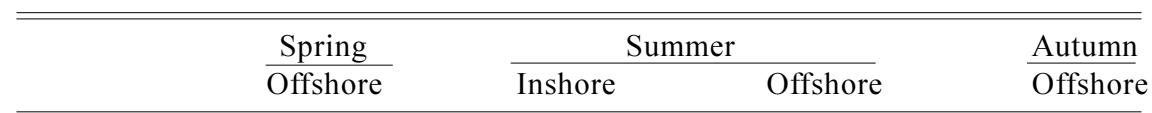

\section{Female density (numbers $/ \mathrm{m}^{2}$ )}

\begin{tabular}{|c|c|c|c|c|}
\hline 1982 & 0.14 & & & 0.14 \\
\hline 1983 & 0.40 & & & 0.26 \\
\hline 1984 & 0.22 & & & 0.10 \\
\hline 1985 & 0.07 & & & 0.08 \\
\hline 1986 & 0.15 & & & 0.05 \\
\hline 1987 & 0.08 & & & 0.12 \\
\hline 1988 & 0.10 & & & 0.14 \\
\hline 1995 & & 0.29 & 0.38 & \\
\hline 1996 & & 0.12 & 0.26 & \\
\hline 1997 & & 0.25 & 0.26 & \\
\hline 1998 & & 0.36 & 0.26 & \\
\hline \multicolumn{5}{|c|}{ Juvenile density (numbers $/ \mathrm{m}^{2}$ ) } \\
\hline 1995 & & 0.19 & 0.31 & \\
\hline 1996 & & 0.07 & 0.08 & \\
\hline 1997 & & 0.20 & 0.17 & \\
\hline 1998 & & 0.29 & 0.29 & \\
\hline
\end{tabular}

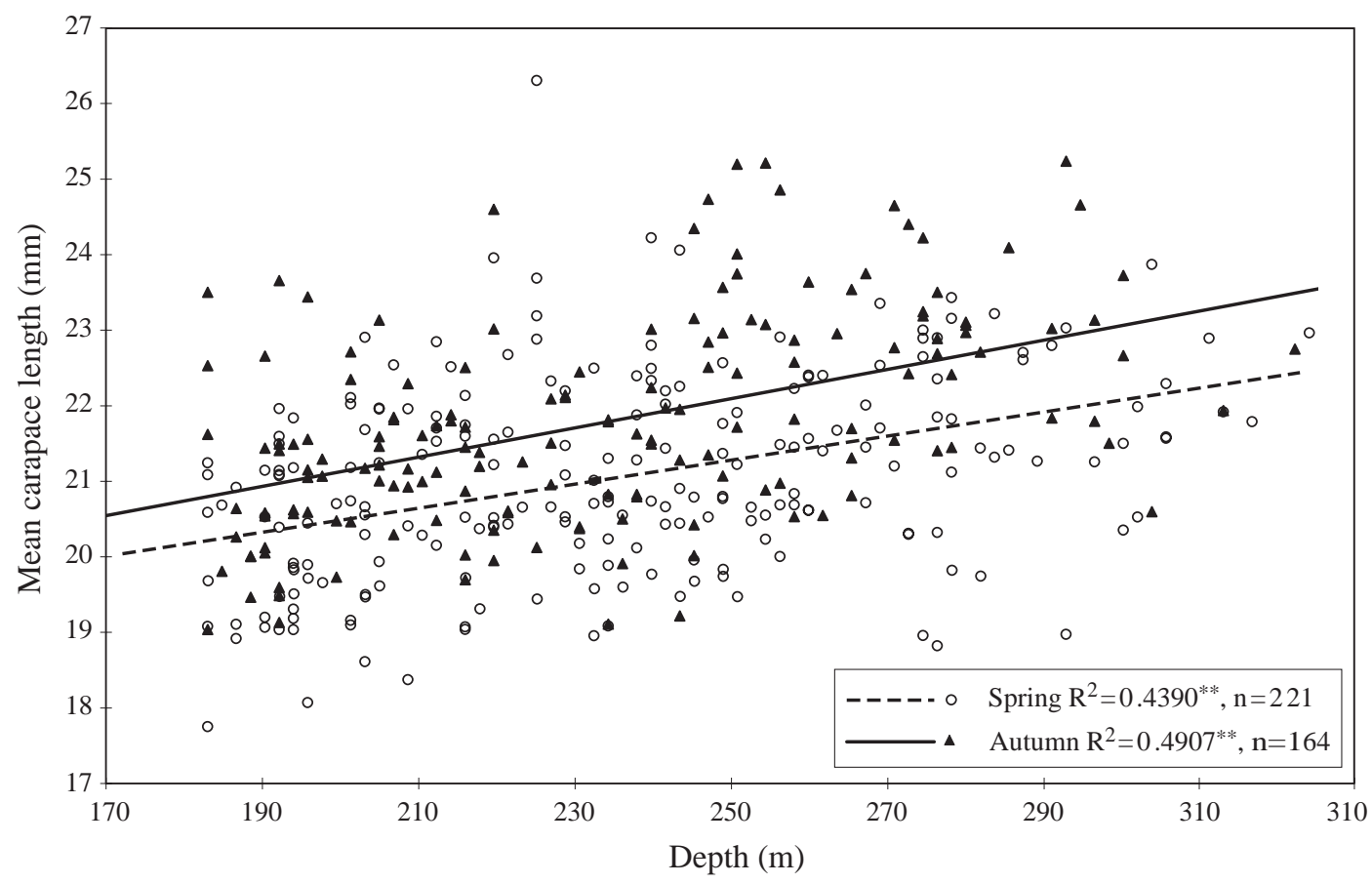

Fig. 4. Mean carapace length versus depth from all shrimp catches taken during spring and fall shrimp surveys conducted from 1982-88 on the eastern Scotian Shelf. 
TABLE 2. Percent composition and mean carapace lengths by developmental stage from samples taken from the Mahone Bay and Canso shrimp trap fisheries in 1997.

\begin{tabular}{|c|c|c|c|c|c|c|c|c|c|c|c|c|}
\hline & \multicolumn{2}{|c|}{ Date } & \multicolumn{2}{|c|}{ Imm. Males } & \multicolumn{2}{|c|}{ Males } & \multicolumn{2}{|c|}{ Transitionals } & \multicolumn{2}{|c|}{ Females } & \multicolumn{2}{|c|}{$\begin{array}{l}\% \text { female } \\
\text { ovigerous }\end{array}$} \\
\hline & Mahone & Canso & Mahone & Canso & Mahone & Canso & Mahone & Canso & Mahone & Canso & Mahone & Canso \\
\hline \multirow{5}{*}{$\begin{array}{l}\text { Percent } \\
\text { Composition }\end{array}$} & 16 Jan & 15 Jan & 0 & 7.0 & 7.4 & 23.3 & 19.7 & 12.6 & 72.9 & 57.1 & 97.6 & 6.9 \\
\hline & 24 Jan & 02 Feb & 0 & 0.2 & 1.8 & 5.8 & 6.1 & 20.7 & 92.1 & 73.2 & 97.7 & 12.5 \\
\hline & $21 \mathrm{Feb}$ & $15 \mathrm{Feb}$ & 0 & 2.0 & 4.0 & 9.1 & 28.8 & 5.2 & 67.2 & 69.9 & 83.7 & 42.1 \\
\hline & 19 Mar & $18 \mathrm{Mar}$ & 0 & 2.1 & 0.2 & 13.7 & 3.2 & 14.2 & 96.6 & 69.9 & 29.2 & 33.9 \\
\hline & & Mean & 0.0 & 2.8 & 3.4 & 13.0 & 14.5 & 13.2 & 82.2 & 67.5 & $93.0^{1}$ & $20.5^{1}$ \\
\hline \multirow{5}{*}{$\begin{array}{l}\text { Mean carapace } \\
\text { length }(\mathrm{mm})\end{array}$} & $16 \mathrm{Jan}$ & $15 \mathrm{Jan}$ & - & 18.9 & 20.2 & 21.5 & 21.0 & 23.4 & 22.9 & 25.6 & & \\
\hline & 24 Jan & 02 Feb & - & 19.0 & 19.7 & 22.1 & 20.8 & 24.0 & 23.2 & 25.8 & & \\
\hline & $21 \mathrm{Feb}$ & $15 \mathrm{Feb}$ & - & 18.1 & 19.6 & 21.9 & 21.3 & 23.6 & 22.7 & 25.6 & & \\
\hline & 19 Mar & $18 \mathrm{Mar}$ & - & 18.3 & 20.0 & 21.9 & 21.2 & 24.3 & 22.6 & 26.2 & & \\
\hline & & & - & 18.6 & 19.9 & 21.9 & 21.1 & 23.8 & 22.9 & 25.8 & & \\
\hline
\end{tabular}

${ }^{1}$ Average prior to March before egg release begins.

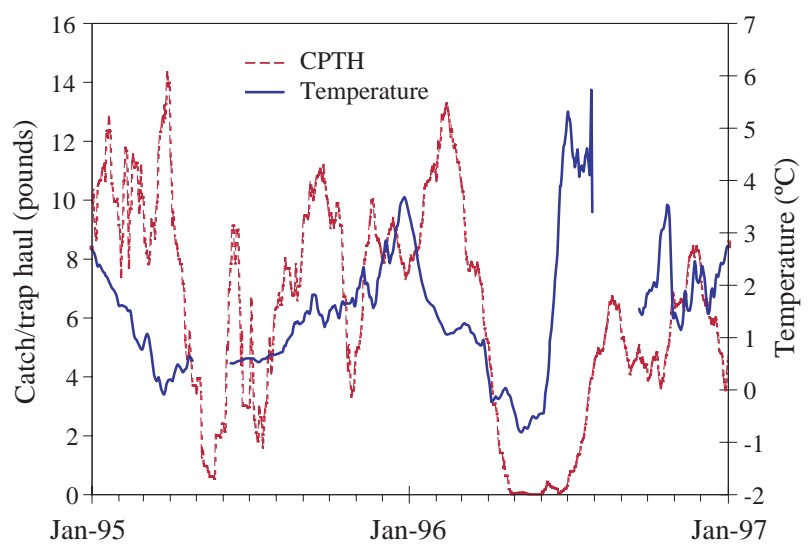

Fig. 5. Average daily commercial catch per trap haul and bottom temperatures in Chedebucto Bay, Nova Scotia during 1995-96.

significant determinant of shrimp abundance in all areas since 1977. Bottom temperatures lagged by 4 years were insignificant in all cases (Table 3 ).

\section{Discussion}

Data from groundfish surveys, exploratory shrimp surveys and the historical shrimp fisheries on the Scotian Shelf and Bay of Fundy show that $P$. borealis form concentrations on the eastern Scotian Shelf (Fig. 1). While shrimp were also present in the central and western shelf region their abundance there was much lower, and the population reached commercially viable densities only once in the historical record. The central and western shelf regions generally have bottom temperatures which are above their preferred temperature range except in the areas where these fisheries occurred, i.e. in Roseway Basin and in the mouth of the Bay of Fundy (Fig. 2). Since temperatures in these areas fell only marginally within the preferred range of the species, and the area of preferred temperatures is small and fluctuates in size (Fig. 3), the sustained favourable conditions needed for a large population increase can be expected only rarely over the long term. The coincidental development of the shrimp fishery in the western Scotian Shelf and the record high catches in the Gulf of Maine in the late1960 s were preceded by a lengthy period of below average temperatures (Fig. 8, 9). The subsequent collapse of the Gulf of Maine fishery and disappearance of the western Scotian Shelf fishery was preceded by a period of above average temperatures. This apparent connection between temperature and shrimp abundance in these areas does not preclude the concurrent influence of other environmental factors or fishing effects. The longstanding controversy in the literature on what regulates the shrimp stock in the Gulf of Maine, "temperature?" (Dow, 1977; Richards et al., MS 1996; Appolonio et al., MS 1984; Tande et al., 1993) or "fishing?" (Anthony and Clark, 1980), in itself suggests that both factors are involved, the answer being dependant on the particular data set and time period under review. This paper shows that in more recent years predation was also an important factor regulating shrimp abundance in all areas examined, including the Gulf of Maine. The 


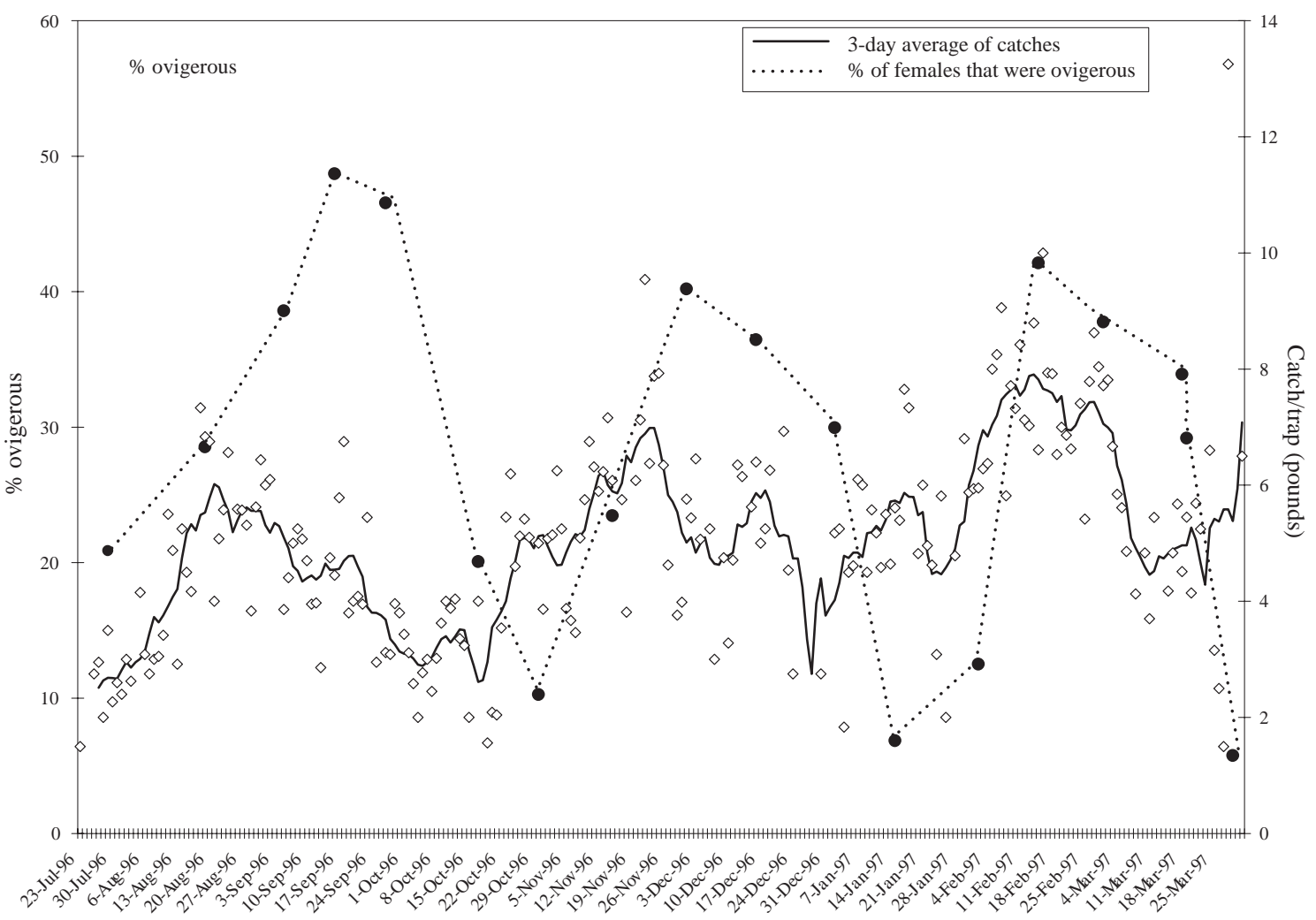

Fig. 6. Average daily commercial catch per trap haul and the percent of females that were ovigerous in commercial trap catch samples during the 1996-97 trap fishing season in Chedebucto Bay, Nova Scotia. Solid line - three-day average of catches; dotted line - percentage of females that were ovigerous.

overriding question that must be answered if this type of information is to be useful in stock management is, what is the relative importance of these factors at any given time?

While the Gulf of Maine and western Scotian Shelf have similarities with regard to shrimp population dynamics, they are different in one important respect long term average abundance in the Gulf of Maine is much higher and, with the exception of the stock collapse in the late-1970s, has managed to sustain a fishery for an extended period. A comparison of the Gulf of Maine, Scotian Shelf, and Newfoundland-Labrador Shelf provides some insight into the relative importance of the known abiotic and biotic factors (i.e. habitat, temperature, depth and predators) to $P$. borealis population dynamics. Marginal temperature conditions in combination with fishing in the Gulf of Maine have resulted in a relatively unstable stock. The more unfavorable temperature conditions in the western Scotian Shelf have resulted in a small population which increases to commercially viable densities only rarely and for short periods of time. On the other hand, the eastern Scotian Shelf shrimp stock is more similar in size, density, and sustainability to the Gulf of Maine. On the eastern Scotian Shelf, shrimp concentrate in small areas of suitable habitat within a large area of favorable temperatures. On the western and central Scotian Shelf, shrimp are restricted to small areas of marginal temperatures despite the availability of large amount of suitable habitat. It is particularly noteworthy that the area with the least amount of preferred habitat i.e. the eastern Scotian Shelf, is the one with the largest shrimp concentrations (Fig. 2, 3). Depth does not appear to be as important as habitat in restricting $P$. borealis to the deep offshore holes on the eastern Scotian Shelf, since large numbers of shrimp are found on suitable habitat in the shallow inshore areas off Cape Breton. Apparently, a combination of suitable temperatures and habitat is a precondition for a high-density population of $P$. borealis with the relative importance of factors in this context being temperature $>$ habitat $>$ depth. Superimposed on these factors is predation, which apparently becomes important when temperature and habitat conditions result in a suitably abundant $P$. borealis population. 

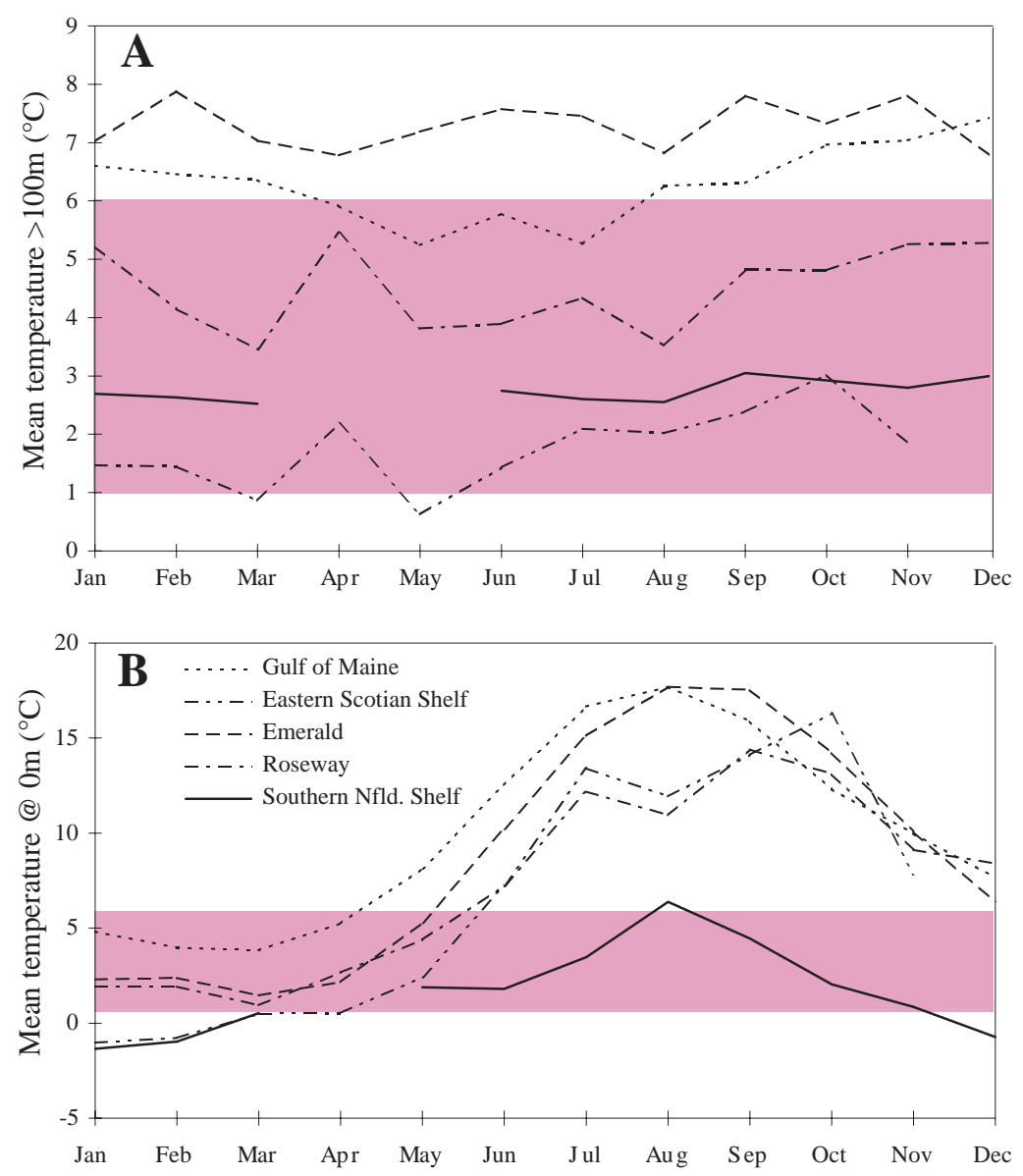

Fig. 7. Monthly mean temperatures for selected areas in the northwestern Atlantic at A) $>100 \mathrm{~m}$ and B) $0 \mathrm{~m}$. The shaded area represents the preferred temperature range of $P$. borealis.

Seasonal temperature differences in shallow and deep water (Fig. 7) can be related to observed differences in shrimp migration patterns and abundance between areas. On the Newfoundland Shelf, average temperatures at depths $>100 \mathrm{~m}$ are near the midpoint of the species temperature range (Fig. 7A). Consequently shrimp do not need to migrate into shallower water to find more favorable temperatures and there are no reports of such migrations in this area. In the Gulf of Maine temperatures at depths $>100 \mathrm{~m}$ are near the upper limit of $P$. borealis temperature range throughout the year but tend to exceed this limit in the autumn and winter. Ovigerous females appear during the autumn and winter in large numbers in the shallow inshore areas (Shumway et al., 1985) where water temperatures remain well within the preferred range (Fig. 7B). They remain in these inshore areas until the early spring. Shrimp are rare in the central Scotian Shelf (Emerald Basin) where the annual water temperatures in depths $>100 \mathrm{~m}$ exceeds the upper temperature limit. Temperatures in the deep water of the western Scotian Shelf (Roseway Basin) are within the temperature range throughout the year, but are near the upper limit during autumn and winter when large numbers of ovigerous females appear nearshore in Mahone Bay (Table 2). On the eastern Scotian Shelf water temperatures are near the lower limit of the species temperature range throughout most of the year. Shrimp are found both inshore and offshore in high densities. During late-winter and early-spring shrimp move into deeper, warmer water immediately outside the Bay when nearshore temperatures in Chedebucto Bay are at or below the lower limit of the temperature range (Fig. 5). It is not clear why ovigerous females move into Chedebucto Bay from the surrounding inshore area from late-summer to spring. The catch patterns of Fig. 6 may simply reflect depletion of accumulated stock in a small area by fishing, and subsequent movement of shrimp into suitable unoccupied habitat from surrounding areas of high density. 

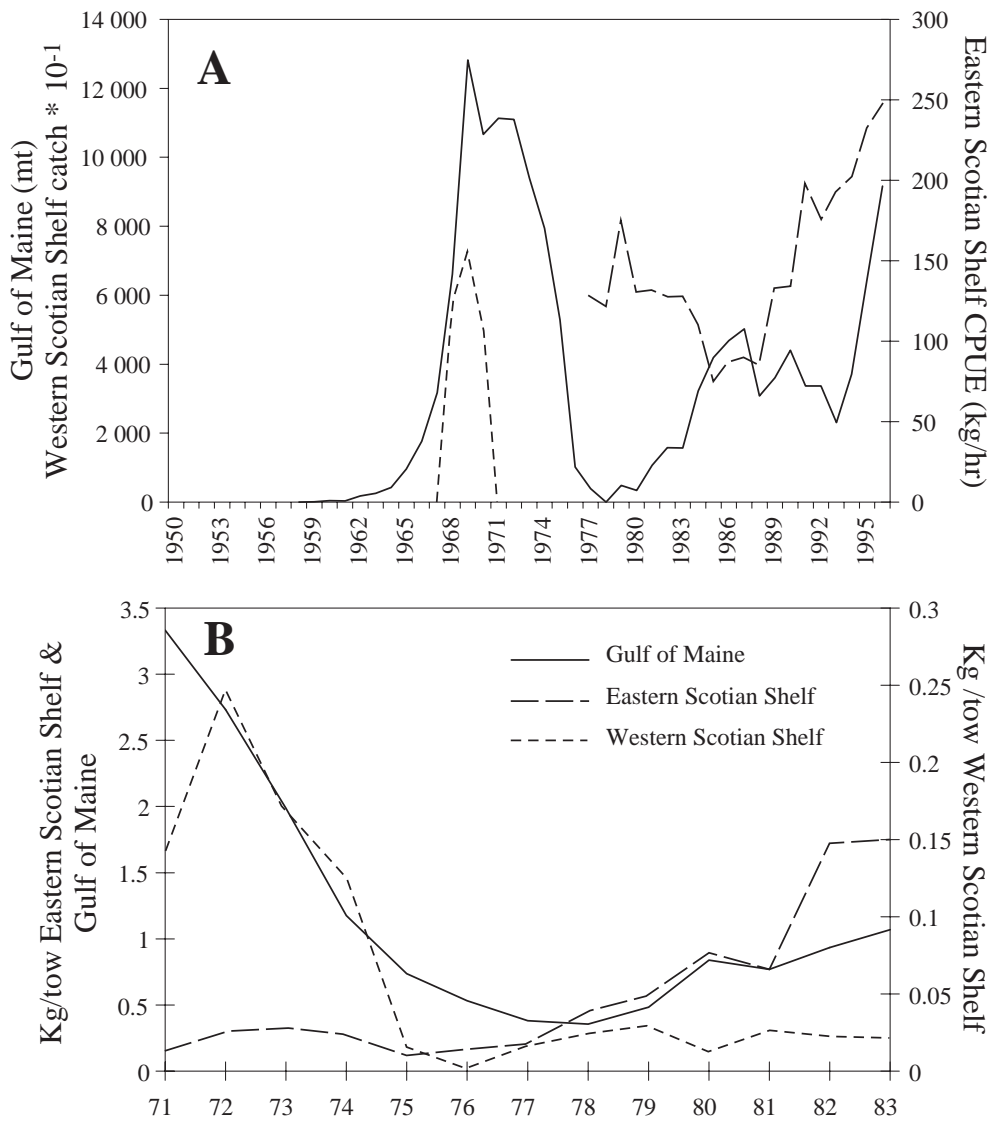

Fig. 8. Changes in shrimp abundance in the Gulf of Maine, western Scotian Shelf and eastern Scotian Shelf as implied from A) landings and commercial catch per unit effort since 1950, and B) stratified mean catch/tow from groundfish surveys since 1971 .

On the Scotian Shelf, P. borealis exhibits migratory behavior with similarities to both the Gulf of Maine and more northern stocks. On the western Scotian Shelf, i.e. Mahone Bay, ovigerous females migrate inshore during winter as in the Gulf of Maine, to find cooler water and/or escape warm water. However, unlike the Gulf of Maine where the fishery follows the shrimp stock inshore in winter and offshore in spring/summer, the western Scotian Shelf shrimp are usually not present offshore in densities suitable for commercial trawling. Recently, the area has only been able to support a small trap fishery, and only after shrimp have concentrated nearshore in small embayments during winter. On the eastern Scotian Shelf, shrimp are present offshore throughout the year in commercial quantities, as occurs in NewfoundlandLabrador and other northern stocks. They are also present inshore throughout the year, however some migration occurs within this area, including nearshore movements in areas with suitable habitat from late summer to early spring, which cease and may be reversed in spring-summer when nearshore temperatures become too cold. There was no evidence of large-scale inshore-offshore migrations on the eastern Scotian Shelf. Offshore, Scotian Shelf shrimp showed local ontogenetic migrations where older animals are found at progressively deeper depths, as in more northern areas (Fig. 4). Normal migration patterns should be considered when evaluating the significance, in terms of stock status, of any change in shrimp distribution. For example, the large decrease in the Gulf of Alaska shrimp stocks in the 1980s has been attributed to climate warming (Anderson, 2000) and was apparently preceded by an inshore movement of the shrimp population (C. Fu, Bedford Institute of Oceanography, Dartmouth, Nova Scotia, personal communication).

In the absence of empirically derived, stock specific targets for exploitation, Pandalid shrimp managers have tended to use a blanket "rule of thumb" approach, despite well documented differences in biological and population characteristics between stocks 

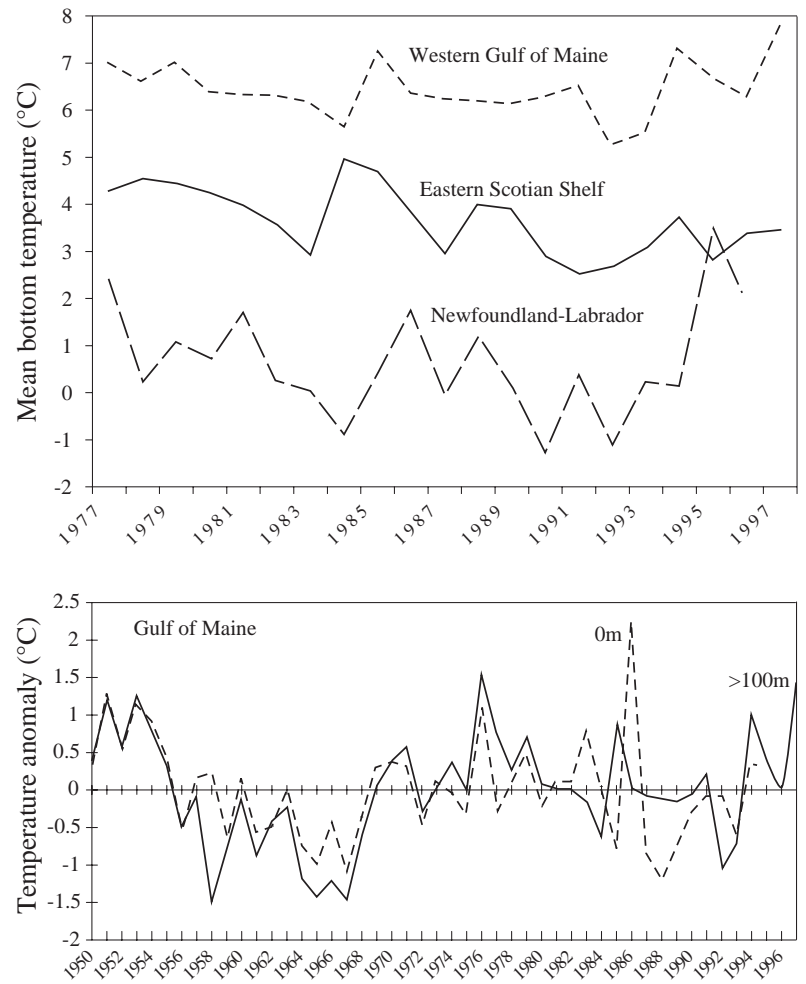

Fig. 9. A) Mean bottom temperatures $(>100 \mathrm{~m})$ from groundfish surveys in the western Gulf of Maine, eastern Scotian Shelf and Newfoundland-Labrador shelf since 1977 and B) long-term temperature anomalies (surface and $>100 \mathrm{~m}$ ) from the Gulf of Maine.

that could result in different reactions to similar exploitation rates (Savard and Parsons, MS 1990). For example, target exploitation rates of $35 \%$ were widely used in eastern Canada until this was exceeded in some areas with no apparent harm to the stock (Mohn et al., 1992). Nilssen and Hopkins (MS 1991) point out that differences in life cycles should be taken into account when developing ecologically acceptable management strategies. The above description of Scotian shelf shrimp biology in relation to more northern and southern populations could have important implications for management in the area.

It is apparent that the western Scotian Shelf cannot sustain a shrimp fishery, yet harvesting opportunities do arise for short periods from time to time. A successful fishery would launch exploratory surveys when temperature conditions are favorable and mobilize/ demobilize rapidly as catch rates increase above and decrease below commercially viable levels. Harvest controls would be introduced only if environmental monitoring suggested a prolonged period of favorable

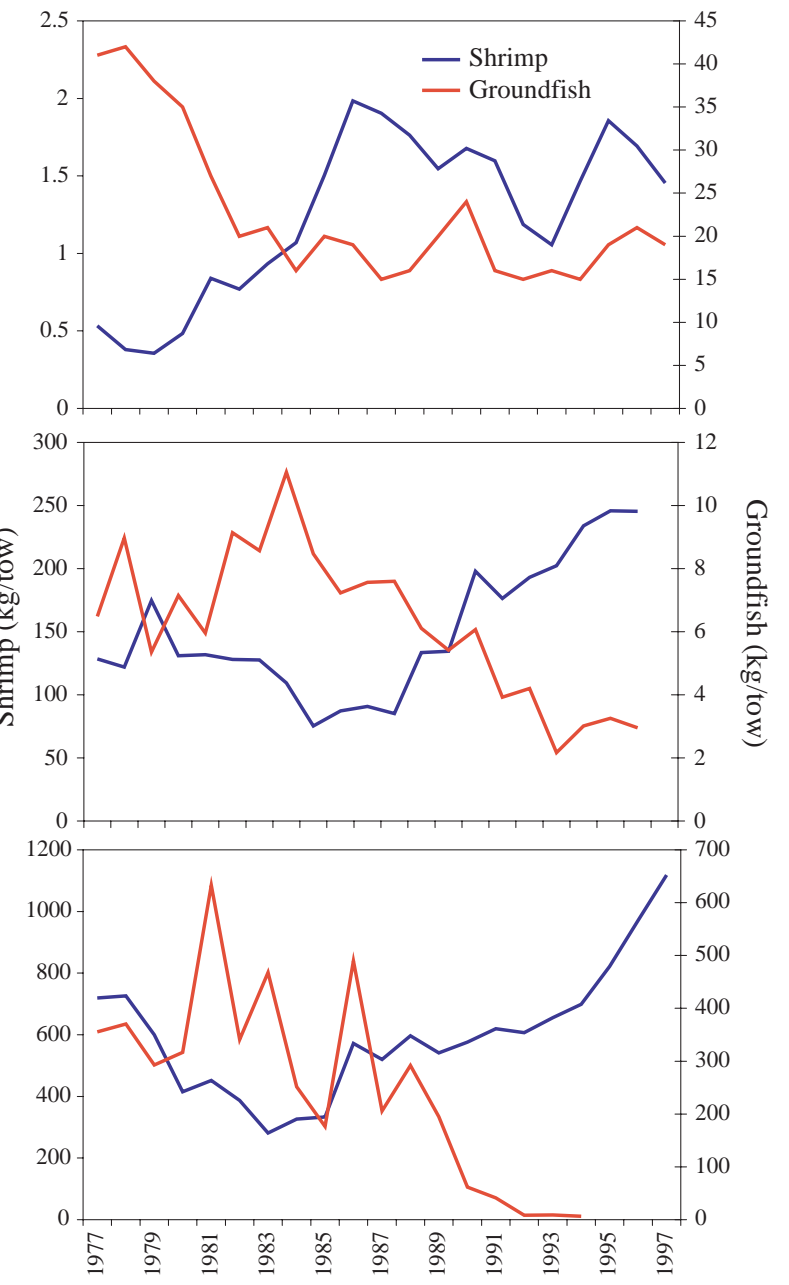

Fig. 10. Shrimp and groundfish catch/tow in the Gulf of Maine, eastern Scotian Shelf and NewfoundlandLabrador Shelf since 1977. All data are from stratified random groundfish surveys except eastern Scotian Shelf and Newfoundland-Labrador Shelf shrimp data, which are commercial CPUE series taken from stock assessment documents.

temperatures and overfishing could precipitate a "premature" stock collapse.

The eastern Scotian Shelf shrimp fishery appears sustainable. However, large changes in abundance occur in the absence of significant fishing pressure due to predation. This suggests a vulnerability to overfishing, including the possibility of collapse when concurrent negative abiotic and biotic factors combine with fishing effects to produce rapid population declines as apparently happened in the Gulf of Maine in the 1970s. The absence of long range inshore-offshore 
TABLE 3. Multiple regression analysis of total groundfish abundance from surveys, shrimp abundance from surveys (Gulf of Maine) and catch per unit effort (Scotian Shelf and Newfoundland-Labrador), and mean bottom temperatures 1977-97.

\begin{tabular}{|c|c|c|c|c|c|c|c|c|c|}
\hline & & Coefficient & Std. Error & t value & $\operatorname{Pr}(t)$ & $\mathrm{R} \mathrm{Sq}$. & $\mathrm{F}$ & Df & $\operatorname{Pr}(F)$ \\
\hline \multirow{3}{*}{ Gulf of Maine } & Groundfish & -0.0596 & 0.0161 & -0.3705 & 0.0030 & \multirow[t]{3}{*}{0.5637} & \multirow[t]{3}{*}{7.7550} & \multirow[t]{3}{*}{$2(12)$} & \multirow[t]{3}{*}{0.0069} \\
\hline & Temperature & 0.0620 & 0.1554 & 0.3990 & 0.6969 & & & & \\
\hline & Intercept & 2.2334 & 0.9395 & 2.3772 & 0.0349 & & & & \\
\hline \multirow{3}{*}{$\begin{array}{l}\text { Eastern Scotian } \\
\text { Shelf }\end{array}$} & Groundfish & -13.4293 & 3.3482 & -4.0109 & 0.0011 & \multirow[t]{3}{*}{0.5230} & \multirow[t]{3}{*}{8.2230} & \multirow[t]{3}{*}{$2(15)$} & \multirow[t]{3}{*}{0.0039} \\
\hline & Temperature & 2.2265 & 10.3870 & 0.2144 & 0.8332 & & & & \\
\hline & Intercept & 217.8580 & 39.1024 & 5.5715 & 0.0001 & & & & \\
\hline \multirow{5}{*}{$\begin{array}{l}\text { Newfoundland- } \\
\text { Labrador }\end{array}$} & Groundfish & -0.6622 & 0.3328 & -1.9896 & 0.0681 & \multirow[t]{3}{*}{0.2504} & \multirow[t]{3}{*}{2.1720} & \multirow[t]{3}{*}{$2(13)$} & \multirow[t]{3}{*}{0.1535} \\
\hline & Temperature & -17.7862 & 31.6720 & -0.5616 & 0.5840 & & & & \\
\hline & Intercept & 659.9467 & 83.7724 & 7.8779 & 0.0000 & & & & \\
\hline & Groundfish & -0.6253 & 0.2242 & -2.7896 & 0.0131 & \multirow[t]{2}{*}{0.3272} & \multirow[t]{2}{*}{7.7820} & \multirow[t]{2}{*}{$1(16)$} & \multirow[t]{2}{*}{0.0131} \\
\hline & Intercept & 647.4811 & 48.9658 & 13.2231 & 0.0000 & & & & \\
\hline
\end{tabular}

migrations on the eastern Scotian Shelf suggests that temperatures are less extreme relative to the species' tolerances and preferences, and that a rapid temperature induced population decline may be a rarer event than in the Gulf of Maine. The lack of a significant correlation between bottom temperature and shrimp abundance on the eastern Scotian Shelf in the present analysis does not preclude such an effect. The time window when temperatures and shrimp abundance indices were available for analysis is very restricted. The area of favorable temperatures surrounding this stock varies significantly over the long term and has resulted in incursions and exclusions of some cold water species such as capelin (Frank et al., 1996). It is particularly noteworthy that the two incursions of capelin since 1970 attributed to anomalous cold temperatures occurred during periods of high shrimp abundance. Stock assessments should flag any concurrent increases in predation, temperatures and fishing effort since they could lead to rapid population decrease and stock collapse.

The strong affinity of eastern Scotian Shelf shrimp for mud substrates and their resulting concentration in small areas is another potential problem, which should be taken into account when considering exploitation levels for this stock. In the Newfoundland-Labrador Shelf, local overfishing will likely result in replenishment from the extensive surrounding shrimp grounds. The Scotian Shelf stock is relatively isolated - it is unlikely that the nearest "upstream" stock in the northern Gulf of St. Lawrence provides significant numbers of viable larvae. The small patches of habitat suitable for adults result in equally small suitable settling sites for juveniles. In a dynamic hydrographic regime where horizontal tidal ranges and larval retention gyres are probably larger than the area of suitable habitat, a higher percentage of larvae will settle on unsuitable substrate. Moreover, the northeasterly Nova Scotia current will carry larvae produced in the eastern Scotian Shelf shrimp holes into unsuitable areas only a few miles to the west. The resulting higher larval mortality for this stock will require a higher spawning stock to maintain any particular target yield and makes the stock more vulnerable to recruitment overfishing.

The above analyses suggest that the management approach to the eastern Scotian Shelf shrimp stock should be more precautionary than for the Newfoundland-Labrador populations, and similar to that of the Gulf of Maine population.

\section{Acknowledgements}

I would like to thank Michelle King, Michele Covey and Marianne Etter for technical assistance in sample and data analysis, and the captains and crews of the DFO research vessels and the commercial shrimp vessels that cooperated in surveys and sample collection. Roger Pettipas and Ken Drinkwater provided temperature information. Two anonymous reviewers contributed significantly to the final revision.

\section{References}

ALLEN, J. A. 1959. On the biology of Pandalus borealis Krøyer, with reference to a population off the 
Northumberland coast. J. Mar. Biol. Assoc. U.K., 38: $189-220$.

ANG, P. MS 1993. Exploratory shrimp survey in Fisheries Zone 4X. DFO Internal Report, $94 \mathrm{p}$.

ANDERSON, J. 2000. Pandalid shrimp as indicators of ecosystem regime shift. J. Northw. Atl. Fish. Sci., 27: $1-10$.

ANTHONY, V. C., and S. CLARK. 1980. A description of the northern shrimp fishery and its decline in relation to water temperature. In: Climate and fisheries: proceedings of a workshop on the influence of environmental factors on fisheries production. Univ. R.I. Tech Rep., 119: 119-121.

APPOLONIO, S., D. K. STEVENSON, and E. E. DUNTON. MS 1984. Effects of temperature on the biology of the northern shrimp Pandalus borealis, in the Gulf of Maine. Dep. Mar. Resour. Res. Ref. Doc., No. 83/30, $60 \mathrm{p}$.

ARMSTRONG, M., S. CADRIN, D. MCCARRON, D. SCHICK, and B. SMITH. 1997. Gulf of Maine Shrimp - 1997. Assessment Report of Northern Shrimp Committee of the Atlantic States Marine Fisheries Commission, $50 \mathrm{p}$.

CADEGAN, E. 1970. Shrimp explorations, 1969-70. Nova Scotia Department of Fisheries Resource Development Division, $9 \mathrm{p}$.

DOUBLEDAY. W. G. 1981. Manual on the groundfish surveys in the northwest Atlantic. NAFO Sci. Coun. Studies, 2: $50 \mathrm{p}$.

DOW, R. L. 1977. Effects of climatic cycles on the relative abundance and availability of commercial marine and estuarine species. ICES J. Cons., 37: 274-280.

ETTER, M. L., and R. K. MOHN. MS 1989. Scotia-Fundy shrimp stock status - 1988. CAFSAC Res. Doc., No. 4, $25 \mathrm{p}$.

FRANK, K. T., J. E. CARSCADDEN, and J. E. SIMON. 1996. Recent incursions of capelin (Mallotus villosus) to the Scotian Shelf and Flemish Cap during anomalous hydrographic conditions. Can. J. Fish. Aquat. Sci., 53: $1473-1486$.

HALLIDAY, R. G., and P. A. KOELLER. 1981. A history of Canadian groundfish trawling surveys and data usage in ICNAF Divisions 4TVWX. In: Bottom trawl surveys. W.G. Doublday and D. Rivard (eds.). Can. Spec. Publ. Fish. Aquat. Sci., 58: 27-41.

JOHNSON, P. 1966. Shrimp explorations in the Bay of Fundy, 1966. N.S. Dept. Fish., Fisheries Project 20166, $9 \mathrm{p}$.

KOELLER, P. A, M. KING, M. B. NEWELL, A. NEWELL, and D. RODDICK. 1995. An inshore trap fishery for eastern Nova Scotia? Can. Tech. Rep. Fish. Aquat. Sci., 2064, $41 \mathrm{p}$.

KOELLER, P.A. MS 1996. Aspects of the biology of shrimp Pandalus borealis on the Scotian Shelf. DFO Atl. Fish. Res. Doc., No. 9, 34 p.

KOELLER, P. A., M. COVEY, and M. KING. MS 1999. The Scotian Shelf shrimp (Pandalis borealis) fishery in 1999. Can. Stock Ass. Secretariat Res. Doc., No. 991/ $172,41 \mathrm{p}$.

MACPHAIL, J. S., and A. MACDONALD. 1965. Shrimp
Explorations, 1965. Nova Scotia Department of Fisheries Project, No. 203, 87 p.

MCCRARY, J. A. 1971. Sternal spines as a characteristic for differentiating between females of some Pandalidae. J. Fish. Res. Board Can., 28: 98-100.

MOHN, R. K., D. G. PARSONS, and L. SAVARD. 1992. Report of Canadian Atlantic Fisheries Scientific Advisory Committee Special Meeting, Invertebrates and Marine Plants Subcommittee, Shrimp Management Alternatives, December 5-8, 1989, Ottawa, Canada. Can. Tech. Rep. Fish. Aquat. Sci., 1884, 30 p.

MURRAY, R. 1967. Shrimp explorations and processing trials 1965-1967. N.S. Dept. Fish, Report on Project, No. 203, $87 \mathrm{p}$.

NOAA. 1998. Status of the Fishery Resources off the Northeastern United States. NOAA Technical Memorandum, NMFS-NE-115.

NILSSEN, E. M., and C. C. E. HOPKINS. MS 1991. Population parameters and life histories of the deep-water prawn Pandalus borealis from different regions. ICES C. M. Doc., No. K:2, 27 p.

PARSONS D. G., and P. J. VEITCH. MS 1998. Status of Northern shrimp (Pandalus borealis) resources in areas off Baffin Island, Labrador, and northeastern Newfoundland - Interim review. DFO Can. Stock Ass. Sec. Res. Doc., No. 72.

PETTIGREW, T. J. 1970. Shrimp industry in the Bay of Fundy, New Brunswick, 1970. Department of Fisheries of New Brunswick Exploratory Fishing Branch, 58 p.

RICHARDS, A., M. FOGARTY, S. CLARK, D. SCHICK, P. DIODATI, and B. O'GORMAN. MS 1996. Relative influence of reproductive capacity and temperature on recruitment of Pandalus borealis in the Gulf of Maine. ICES C. M. Doc., No. K:13, 7 p.

SAVARD, L., and D. G. PARSONS. MS 1990. Geographic variations in the life history of Pandalus borealis from the Northwest Atlantic. ICES Symposium on Shellfish Life Histories and Shellfishery Models, Paper, No. $27,4 \mathrm{p}$.

SCULLION, D. F. 1969. Shrimp Industry in the Bay of Fundy, New Brunswick 1968-69. Department of Fisheries of New Brunswick Exploratory Fishing Branch, $39 \mathrm{p}$.

SHUMWAY, S. E., H. C. PERKINS, D. F. SCHICK, and A. P. STICKNEY. 1985. Synopsis of biological data on the pink shrimp, Pandalus borealis Krøyer, 1838. FAO Fisheries Synopsis, No. 144, 57 p.

STEFÁNSSON, G., and Ó. K. PÁLSSON. MS 1998. A framework for multispecies modeling of Arcto-boreal systems. Rev. Fish Biol. Fish., 8(1): 101-104.

STEFÁNSSON, G., U. SKÚLADÓTTIR, and G. PÉTURSSON. 1994. The use of a stock production type model in evaluating the offshore Pandalus borealis stock of north Icelandic waters, including the predation of northern shrimp by cod. ICES C. M. Doc., No. K:25, 13 p.

TANDE, K. S., T. RASMUSSEN, and G. PEDERSON. 1993. Thermal increase enhancement: a possible link between recruitment and climate in high latitude environments. ICES Mar. Sci. Sym., 198: 502-509. 